\title{
Coarctation Balloon Angioplasty in A Four Months Old Infant Following End to End Coarctation Repair: A Case Report
}

\author{
NURUN NAHAR FATEMA
}

\section{Introduction}

Aortic coarctation indicates a narrowing at some point along the course of aorta. Descrete coarctation is much commoner than tubular hypoplasia. Bonnet divided coarctation into infant type, occurring proximal to the aortoductal junction with patency of ductus and as adult type, tending to occur distally to the point of insertion of arterial ligament ${ }^{1}$. An infant with severe coarctation of the aorta may present with symptoms of congestive heart failure, having been well days before. Subsequently they may develop renal failure and feature of hypoperfusion to other organs. So the infant becomes acutely, seriously and even critically $\mathrm{ill}^{2}$. Any infant with such critical symptoms need urgent intervention which includes medical management, surgical intervention and balloon angioplasty. Here we are reporting a case of coarctation of aorta who needed balloon angioplasty at 4 month of age after end to end anastomosis surgery for complete cure.

\section{Case Report}

A 4 months old female baby had history of respiratory distress since 10 days of her life. She had her first echocardiographic examination of heart on $12^{\text {th }}$ day of life and ventricular septal defect was detected. She developed renal failure on next day and subsequently diagnosed as a case of descrete coarctation of aorta on $15^{\text {th }}$ day. She was then operated in a private hospital where an end to end anastomasis of aorta was performed after excision of coarct segment. Patient's renal function improved, but she remain persistently hypertensive since her immediate postoperative period. She was taking Nifedipine $10 \mathrm{mg}$ daily but there was no improvement. Later she reported to paediatric cardiologist of Combined Military Hospital $(\mathrm{CMH})$ Dhaka at the age of 4 months. Her echocardiography showed severe residual coarctation of aorta with peak pressure gradient of $95 \mathrm{~mm} \mathrm{Hg}$ across coarct segment. Diameter of coarct area was $2.5 \mathrm{~mm}$. Next day on $7^{\text {th }}$ December, 2008 she was taken into the catheterization laboratory of Combined

Paediatric Cardiologist, Dhaka Cantonment, Dhaka Correspondence: Dr. Lt Col Nurun Nahar Fatema
Military Hospital Dhaka with an intention of balloon angioplasty. She was sedated with injection Ketamine and injection Midazolam and drapped properly. Right femoral vein and artery were cannulated with 5 French sheath. Aortogram was performed with a multipurpose catheter and a pinhole opening noticed at coarct segment (Fig.-1). Pressure gradient across coarct segment was $70 \mathrm{~mm} \mathrm{Hg}$. Catheter was exchanged with 0.035 wire. Gradual balloon dilatation was performed with $4 \mathrm{~mm} \times 2 \mathrm{~cm}, 6 \mathrm{~mm} \times 2 \mathrm{~cm}$ and $8 \mathrm{~mm} \times 2 \mathrm{~cm}$ balloon (Fig.-2). Post balloon angioplasty pressure gradient was $14 \mathrm{~mm} \mathrm{Hg}$. No complication was observed in catheterization laboratory and in post cath observation room. Special precaution was taken to manage hypertensive crisis, but patient's blood pressure returned to normal after successful balloon angioplasty. She was discharged from hospital on next day with tab Nifedipine $2.5 \mathrm{mg}$ twice daily dose. Her echocardiography before discharge showed no residual coarctation. Follow up was adviced at 1, 3, 6, 9, 12, 18, 24 months and yearly thereafter for three years.

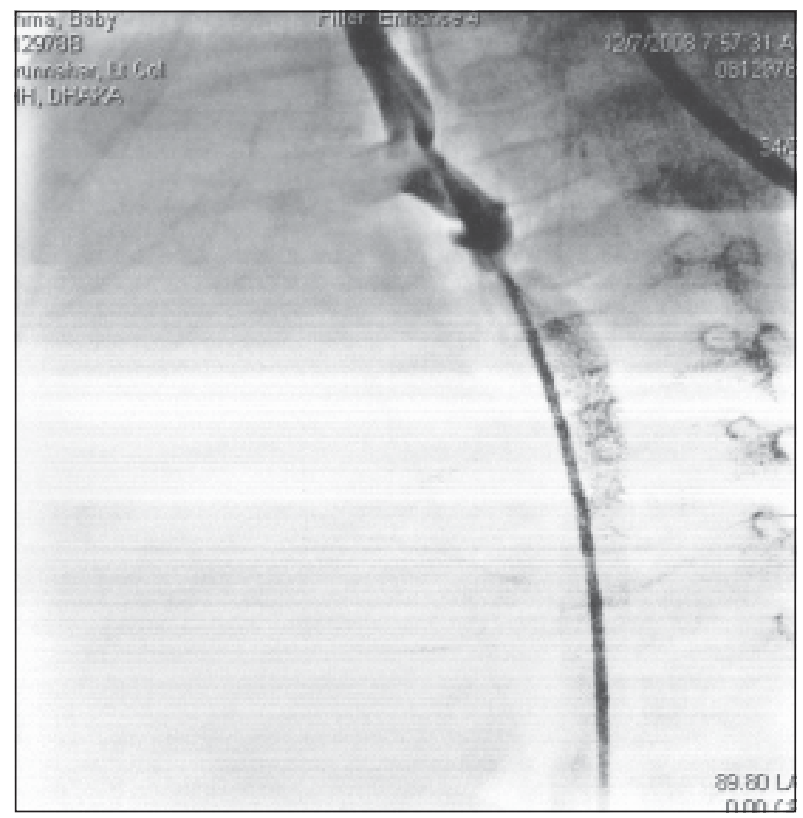

Fig.-1: Aortogram showing coarctation area before balloon angioplasty 


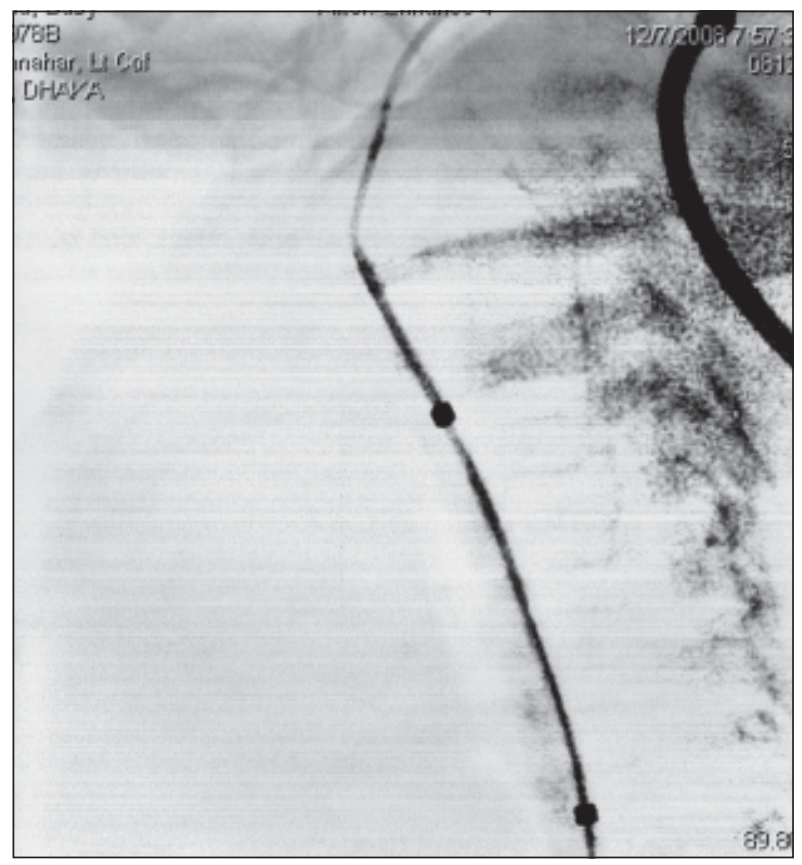

Fig.-2: showing inflated balloon inside coarct area

\section{Discussion}

The management of patients presenting with coarctation in infancy is revolutionized by the invention of prostaglandin $\mathrm{E}$ and its use to maintain and restore the patency of the ductus ${ }^{1}$. Infants presenting with preductul coarctation have heart failure, shock and deteriorating renal function, which could be reversed by maintaining the lower body circulation through ductus $^{1-4}$. In any infant, becoming shocked within the first few weeks of life and in whom lower limb pulses are absent, it should be mendatory to start prostaglandin along with other resuscitatory maneuvers while expert assistance is sought. Coarctation of aorta can occur as an isolated defect or in association with a patent ductus arteriosus (PDA), ventricular septal defect (VSD), or aortic stenosis. It can often be a part of Taussig Bing anomaly or shones comple $x^{5}$. It can be a descrete or long segment defect associated with variable degree of hypoplasia of the isthmas or transverse arch. In present case, coarctation was descrete and preductal in location. The indications for balloon angioplasty of the aorta are: 1 . Native or recurrent obstruction with a gradient of $>20 \mathrm{mmHg}$. 2 . Coarctation where there is left ventricular hypertrophy or systemic hypertension.

In neonates and infants $<1$ year of age with native coarctation surgical resection and repair are recommended ${ }^{1-5}$. Transcatheter therapy is the treatment of choice in $>1$ year age with a well developed isthmus. Balloon angioplasty is one of the modality of transcatheter treatment ${ }^{6}$. A balloon catheter 2-3 times the diameter of coarctation segment but not exceeding the diameter of the adjacent arch proximal to the narrowed segment is selected and inflated across the coarctation site ${ }^{7-10}$. In this case coarctation had a pinhole opening only and diameter was $1.5 \mathrm{~mm}$. So, gradual dilatation of the coarctation area was performed with $4 \mathrm{~mm} \times 2 \mathrm{~cm}, 6 \mathrm{~mm} \times 2 \mathrm{~cm}$ and $8 \mathrm{~mm}$ by $2 \mathrm{~cm}$ balloon. Stent implantation in the coarctation area is another modality of treatment for older children. Published reports of balloon angioplasty demonstrates that this procedure results in short term effective relief of gradient in $75-90 \%$ of patients and a low mortality of $0.7-02.5 \%{ }^{11,12}$. Long term follow up revealed re-stenosis in $25-36 \%$ cases $^{13-17}$. VACA (Valvuloplasty and Angioplasty for Congenital Anomalies) registry data reported suboptimal outcome in $19 \%$ of native and $25 \%$ of recurrent lesions ${ }^{11}$. The study was conducted among 970 patients from 25 centres. The major draw back of the angioplasty alone is recoil of the vessel wall with recurrence of stenosis ${ }^{5}$. Balloon angioplasty may cause aortic wall dissection in 1-4\% of patients and aneurysm formation in 4-11.5\% patient ${ }^{18,19}$. Another study reports that the immediate gradient reduction was similar in both surgery and angioplasty case but the incidence of aneurysm formation and re-stenosis is more after balloon angioplasty ${ }^{20}$.

\section{Conclusion}

Transcatheter therapy for native and recurrent coarctation is effective with good short and intermediate term result. The current trend is for primary stent implantation, however the results of balloon angioplasty in children and young adult are equivalent to those with primary stent placement. A neonate and young infant should be treated immediately to avoid complications like renal failure and other organ damage from effect of hypoperfusion. In present case, first echocardiography report was incorrect, she then developed renal failure and work up for that revealed coarctation of aorta. End to end anastomosis surgery performed in a private hospital was not successful and later on balloon angioplasty cured her. Message here is that, aortic arch of every infant and children should be studied during echocardiography and this kind of critical cases 
should be managed in proper hospitals rather than in private clinics.

\section{References}

1. Anderson R. S. Paediatric Cardiology. Newyork: Churchil Livingstone; 2002. P.1323-57.

2. Nadas AS, Fyler DC. Nadas Paediatric Cardiology. Philadelphia: Hanley and Belfas; 1992. P. 683.

3. Adams FT, Emmanoulides GC, Rimenschneider TA. Heart disease in Infant, Children and Adolescents, $5^{\text {th }}$ ed. Baltimore: Williams and Wilkins; 1995. P. 1111-32.

4. Jeffery J Pomerane, Joan Richardson. A Neonatology for the clinical Practice. Norwalk (Cunnecticut): Appleton and Lange; 1993. P. 633.

5. Horvath R, Towgood A, Sandhu SK. Role of transcatheter therapy in the treatment of coarctation of aorta. J Invasive Cardiol 2008; 20: 660-63.

6. Fatema NN, Rahman SMM. Balloon angioplasty of coarctation of abdominal aorta-A case report. Bangladesh Armed Forces Medical College Journal 2003; 32: 95-98.

7. Beckman RH, Roccini AP, Dick M. Percutaneous balloon angioplasty for native coarctation of aorta. J Am Col Cardiol 1987; 10: 1078-84.

8. Rudloph AM, Heyman MA. Haemodynamic consideration in the development of narrowing of the aorta. Am J Cardiol 1972; 30: 514-25.

9. Cobanoglu A, Teply TF, Grunkemeier GL. Coarctation of the aorta in patients younger than 3 months. J Thorac Cardiovasc Surg 1985; 89: 128-35.

10. Yetman AT, Nykanen D, McCrindle B, Balloon angioplasty of recurrent coarctation. A 12 year review. J Am Coll Cardiol 1997; 30: 811-16.

11. McCrindle BW, Jones TK, Moaow WE. Acute follow up results of balloon angioplasty of native coarctation versus recurrent aortic obstruction are equivalent. Valvoplasty and Angioplasty for Congenital anomalies (VACA) registry investigations. J Am Coll Cardiol 1996; 28: 1810-17.

12. Hellenbrand WE, Allen HD, Golinki RJ. Balloon angioplasty for aortic coarctation: Results of valvuloplasty and Angioplasty of congenital anomaly registry. Am J Cardiol 1990; 65: 793-97.

13. Rui A, Qureshi S, Rosenthal E. Determinants of Haemodynamic results of balloon dilatation of aortic recoarctation. Am J Cardiol 1992; 69: 665-71.

14. Fletcher SE, Nihil MR, Grifko RJ. Balloon angioplasty of native coarctation of the aorta: Midterm follow up and prognostic factors. J Am Coll Cardiol 1995; 25: 730-34.

15. Mendel Sohn AM, Lioyd TR, Crowley DC. Late follow up of balloon angioplasty in children with a native coarctation of the aorta. Am J Cardiol 1994; 74: 696-700.

16. Hijazi ZM, Fahey JT, Kleinman CS, Hellenbrand WE. Balloon angioplasty for recurrent coarctation of aorta. Immediate and long term results. Circulation 1991; 84: 1150-56.

17. Rao PS, Thaper MK, Galal O, Wilson AD. Follow up result of balloon angioplasty of native coarctation in neonates and infant. J Invasive Cardiol 1990; 120: 1310-14.

18. Ray DG, Subramanyam R, Titus T. Balloon Angioplasty of native coarctation in neonates and infants 1990; 120: 1310-14.

19. Overt C, Benson LN, Nykanen D, Freedom RM. Transcatheter treatment of coarctation of aorta: A review. Pediatr Cardiol 1998; 19: 27-44.

20. Shaddy RE, Moucek MM, Sturtevent JE. Comparison of angioplasty and surgery for unoperated coarctation of aorta. Circulation 1993; 87: 743-49. 